\title{
Seed Germination Strategies of Desmostachya bipinnata: A Fodder Crop for Saline Soils
}

\author{
Salman Gulzar, ${ }^{1}$ M. A. Khan, ${ }^{2}$ and Xiaojing Liu $^{3}$ \\ Authors are ${ }^{1}$ Assistant Professor and ${ }^{2}$ Professor, Department of Botany, University of Karachi, Karachi 75270, Pakistan; and ${ }^{3}$ Associate Professor, Centre \\ for Agricultural Resources Research, Institute of Genetics and Development Biology, Chinese Academy of Sciences, 286 Huaizhang Road, Shijiazhuang,
} Hebei 050021, China.

\begin{abstract}
Desmostachya bipinnata (L.) Stapf. (Poaceae), or drub, a perennial grass of near-coastal and inland deserts, is a potential fodder crop for either saline soils or where only brackish water is available for irrigation. The responses of $D$. bipinnata seeds under various salinity $(0,100,200,300,400$, and $500 \mathrm{mM} \mathrm{NaCl})$, temperature $\left(10^{\circ}-20^{\circ}, 15^{\circ}-25^{\circ}, 20-30^{\circ}\right.$, and $\left.25^{\circ}-35^{\circ} \mathrm{C}\right)$ and light (12:12-h dark:light and 24-h dark) regimes were investigated. All seeds germinated under nonsaline conditions, however, increase in salinity resulted in a progressive decrease in germination, and few seeds germinated at $500 \mathrm{mM} \mathrm{NaCl}$. Change in temperature had little effect on seed germination under nonsaline conditions, however, seed germination was inhibited under cooler saline conditions. The germination under saline conditions improved at warmer temperature regimes. Seed germination under nonsaline control in dark was similar to those of seeds germinated in light. However, at high salinities, seed germination was substantially inhibited in dark in comparison to those germinated in light. When ungerminated seeds were transferred to distilled water they germinated immediately, and those from higher salinity and temperature regimes had higher recovery. The ability of seeds to germinate over a range of salinity and temperature regimes suggests possibilities for sustainable use of this species as a cash crop in saline soils.
\end{abstract}

\section{Resumen}

El Desmostachya bipinnata (L.) Stapf. (Poaceae), un zacate perenne que crece cerca de las costas y en el interior de los desiertos, es una especie con potencial forrajero tanto para suelos salinos como para áreas en las que solo se dispone de aguas residuales para irrigación. Se investigó la respuesta de semillas de D. bipinnata a varios regimenes de salinidad $(0,100,200,300,400$ y $500 \mathrm{mM} \mathrm{NaCl})$, temperatura $\left(10^{\circ}-20^{\circ}, 15^{\circ}-25^{\circ}, 20^{\circ}-30^{\circ}\right.$ y $\left.25^{\circ}-35^{\circ} \mathrm{C}\right)$ y luz $(12: 12 \mathrm{~h}$ oscuridad: luz y $24 \mathrm{~h}$ de oscuridad). Todas las semillas germinaron bajo condiciones de no salinidad, pero, al incrementar la salinidad se redujo progresivamente la germinación y solo pocas semillas germinaron a $500 \mathrm{mM} \mathrm{NaCl}$. Bajo condiciones de no salinidad, los cambios de temperatura tuvieron un efecto mínimo en la germinación de las semillas, sin embargo, la germinación se inhibió bajo condiciones de salinidad y bajas temperaturas. La germinación bajo condiciones salinas mejoró en los regimenes de temperaturas altas. La tasa de germinación bajo condiciones de no salinidad (control) fue igual en la oscuridad que en presencia de luz. Sin embargo, en altos niveles de salinidad, la germinación fue substancialmente inhibida en la oscuridad. Cuando las semillas sin germinar se transfirieron a agua destilada germinaron inmediatamente y las provenientes de altos niveles de salinidad y temperatura tuvieron una mayor recuperación. La capacidad de las semillas para germinar en un amplio rango de salinidad y temperatura sugiere la posibilidad de utilizar de esta especie como un cultivo generador de ingresos en suelos salinos.

Key Words: grass, halophyte, Karachi, light, recovery, temperature

\section{INTRODUCTION}

Perennial halophytic grasses constitute a valuable fodder and cash crop resource on saline and alkaline wastelands (Lieth et al. 1999; Dagar et al. 2004) besides ecological applications, such as landscaping or rehabilitation, of damaged ecosystems (Debez et al. 2004). Several salt-tolerant grasses are an easily available feed supplement, such as Aeluropus lagopoides (Linn.) Trin. Ex Thw. and Sporobolus madraspatanus Bor. in India and Pakistan (Joshi and Bhoite 1988; Gulzar 2002). These grasses could be used as fodder crops for saline areas or

M.A.K. was funded by the University of Karachi.

At the time of the research, Gulzar was an Assistant Professor, Dept of Botany, Government Superior Science College, Shah Faisal Colony, Karachi 75230, Pakistan.

Correspondence: M. Ajmal Khan, PO Box 8452, University of Karachi, Karachi 75270, Pakistan. Email: halophyte_ajmal@yahoo.com

Manuscript received 24 April 2006; manuscript accepted 8 April 2007. where irrigation water is of poor quality. Direct-seeding propagation method is efficient and quick; therefore, better understanding of germination responses under saline conditions is essential for sustainable use of salt-tolerant grasses (Noe and Zedler 2000).

Halophytic grasses vary significantly in their response to salinity, which appears to influence their distribution along steep salinity gradients (Dodd and Donovan 1999; Khan and Gulzar 2003; Redondo et al. 2004). Generally, seed germination declines progressively with rising salinity levels (Mahmood and Malik 1996; Al-Khateeb 2006); seeds of some species show no effect at $100 \mathrm{mM} \mathrm{NaCl}$ (Gulzar 2002; Al-Khateeb 2006), whereas others showed no effect at $200 \mathrm{mM} \mathrm{NaCl}$ (Hester et al. 1998; Perez et al. 1998; Shen et al. 2003). Some grass species show salt stimulation at low salt concentrations e.g., $5 \mathrm{dS} \cdot \mathrm{m}^{-1}$ or about $50 \mathrm{mM} \mathrm{NaCl}$ (Mahmood and Malik 1996). Joshi et al. (2005) reported salt tolerance of up to $0.5 \%$ (107 mM $\mathrm{NaCl}$ ) for A. lagopoides and S. madraspatanus, whereas none 
of their seeds germinated above that level. Halopyrum mucronatum (L.) Stapf. (Khan and Ungar 2001) and Sporobolus virginicus L. Kunth (Breen et al. 1997) could germinate in up to $350 \mathrm{mM} \mathrm{NaCl}$, whereas some seeds of Urochondra setulosa (Trin.) C. E. Hubb., A. lagopoides, and Sporobolus ioclados Nees ex Trin. Nees, germinated at $500 \mathrm{mM} \mathrm{NaCl}$ (Gulzar and Khan 2001; Gulzar et al. 2001; Khan and Gulzar 2003).

Temperature is also an important factor affecting seed germination under saline and nonsaline conditions (Khan and Ungar 1997a) probably because of its effect on the structural integrity and activity of enzymes (Bewley and Black 1994). Seeds completely failed to germinate in the presence of moisture at low temperatures, whereas higher temperatures could also suppress seed germination (Gulzar and Khan 2001). The optimal temperature required for seed germination of most grasses as well as dicots from coastal and inland areas of Pakistan is $20^{\circ}-30^{\circ} \mathrm{C}$ (Gulzar 2002; Khan and Gul 2006), which is similar to the prevailing temperature regime after the monsoon rains.

Halophytes show remarkable recovery of germination after exposure to hypersaline conditions (Keiffer and Ungar 1997; Shen et al. 2003) with values equal to those of nonsaline controls (Zia and Khan 2004) at optimal temperatures. Prolonged exposure to salinity could promote or inhibit seed germination and the recovery response may vary with the duration and intensity of exposure to salt stress in their natural habitat (Keiffer and Ungar 1997). Although in other cases, $<10 \%$ of ungerminated seeds died due to salt toxicity (Khan and Gulzar 2003). Ability of seeds to recover from salt stress could be crucial for the successful establishment under optimal environmental conditions following reduction in salt levels by rainfall or flooding by irrigation water in agricultural systems (Shen et al. 2003). It could also provide multiple opportunities for cohort establishment in unpredictable saline environments (Khan and Ungar 1997a).

Light is known to regulate seed germination, and most local halophytic grasses showed lower germination in the absence of light, especially at higher salinities (Khan and Gulzar 2003). Seed burial in sand by wind in natural habitat or by tillage in cultivated fields would reduce light intensity, and measurable quantities of light do not penetrate depths greater than a few millimeters (Tester and Morris 1987). Light and salinity interact to reduce germination in a number of halophytes, such as Allenrolfea occidentalis (S. Wats.) Kuntze (Gul and Weber 1999), Limonium stocksii (Boiss.) O. Kuntze (Zia and Khan 2002), and in 4 desert shrubs and a forb (Khan and Ungar 1997b). Interaction of light with temperature is more inhibitory at constant temperature and in dark than diurnally fluctuating light and temperature conditions (Godoi and Takaki 2004).

D. bipinnata is a $\mathrm{C}_{4}$ perennial grass, native to the Sudanian region, from Northern Africa (Morocco to Somalia), Sicily, and Cyprus through the Middle East to Central Asia, Pakistan, and India (Cope 1982), and has been introduced into Southeast Asia (Aronson 1989). The stem and root are used for Ayurvedic medicine in India. The plant occurs as a weed in agricultural areas and is considered to have salt tolerance of $<5.6 \mathrm{dS} \cdot \mathrm{m}^{-1}$ $(60 \mathrm{mM} \mathrm{NaCl})$ on dilutions of Mediterranean Sea water (Aronson 1989). The plant propagates through its rhizome after monsoon rains and also produces numerous flowers and seeds twice a year during June and October. Young leaves are browsed by cattle (Joshi and Bhoite 1988).

The present study tested the following hypotheses: 1) seeds of D. bipinnata germinate better under freshwater conditions, 2) seed germination occurs at $\mathrm{NaCl}$ concentrations higher than $400 \mathrm{mM}, 3$ ) changes in thermoperiod affect seed germination, 4) seeds germinate more (to a greater percentage) during photoperiods than during the dark, 5) seeds germinate rapidly under nonsaline conditions, 6) seeds exposed to high salinity germinate when the salinity stress is removed, and 7) changes in temperature regime affect seed viability under saline conditions.

\section{MATERIALS AND METHODS}

Spikelets of D. bipinnata were harvested from 3 different populations on the Karachi University campus during 2004 and 2006. Seeds were separated from the inflorescence, cleaned, and dry-stored at room temperature. Six salinity concentrations $(0,100,200,300,400$, and $500 \mathrm{mM} \mathrm{NaCl})$ were used, based on preliminary test for salt tolerance of the species. Values for water potential $\left(\psi_{w}\right)$ of corresponding $\mathrm{NaCl}$ solutions were measured with the help of the dew-point microvolt meter model HR-33T (Logan, Utah) on Whatman No. 2 filter paper disks dipped with the corresponding salt solution placed in a C52 sample chamber at $35^{\circ} \mathrm{C}$. Lang (1967) reported that $\psi_{w}$ values may, however, vary a little with change in temperature. Germination was tested on freshly collected seeds in programmed incubators (Percival) at $10^{\circ}-20^{\circ}, 15^{\circ}-25^{\circ}, 20^{\circ}-30^{\circ}$, and $25^{\circ}-35^{\circ} \mathrm{C}$ temperatures at 2 photoperiod regimes: a 12:12 hour dark:light $\left(25 \mu \mathrm{M} \cdot \mathrm{m}^{-2} \cdot \mathrm{s}^{-1}, 400-700 \mathrm{~nm}\right.$ Sylvania cool-white fluorescent lamps) and a 24-hour dark photoperiod. The temperatures used were based on mean values from meteorological data recorded over the past 100 years. Twentyfive seeds each were placed in 4 airtight, sterilized, plastic petri plates with $5 \mathrm{~mL}$ of test solution. The resulting factorial experiment was $6 \times 4 \times 2$ (salinity $\times$ thermoperiod $\times$ photoperiod) arranged in randomized-block design with 3 blocks (seed lots). Seeds were considered to have germinated at radicle emergence (Bewley and Black 1994), and germination was noted on alternate days. To evaluate rate of germination, mean germination time was calculated with the help of the Edmond and Drapala (1958) method denoted as mean days for emergence and expressed by

$$
M_{\text {days }}=\frac{\Sigma N_{i} G_{i}}{\Sigma G_{i}}
$$

where $G_{i}$ is the number of seedlings emerged on the day of observation, and $N_{i}$ is number of days between the day of sowing and the day of observation. After 20 days, all ungerminated seeds were placed in distilled water under the initial temperature regimes for another 20 days. The percentage recovery of ungerminated seeds $(R U)$ was determined using the relation

$$
R U=\frac{a-b}{c-b} \times 100
$$


Table 1. ANOVA of seed germination in 3 seed lots (Lot) of Desmostachya bipinnata by salinity (S), temperature $(\mathrm{T})$, photoperiod $(\mathrm{P})$, and their interactions.

\begin{tabular}{lccrr}
\hline Source & Sum of squares & Mean squares & df & \multicolumn{1}{c}{$\mathrm{F}$} \\
\hline Lot & 356 & 178 & 2 & $2^{1}$ \\
S & 112204 & 22441 & 5 & $229^{2}$ \\
T & 48640 & 16213 & 3 & $166^{2}$ \\
P & 20176 & 20176 & 1 & $206^{2}$ \\
S $\times$ T & 11285 & 752 & 15 & $8^{2}$ \\
S $\times$ P & 5087 & 1017 & 5 & $10^{2}$ \\
T $\times P$ & 248 & 82 & 3 & $1^{1}$ \\
S $\times$ T $\times$ P & 17531 & 1169 & 15 & $12^{3}$ \\
Error & 9202 & 98 & 94 & \\
\hline
\end{tabular}

${ }^{1}$ Nonsignificant.

${ }^{2} P<0.0001$

${ }^{3} P<0.01$.

where $a$ is total number of seeds germinated after being transferred to distilled water, $b$ is the total number of seeds germinated in saline solution, and $c$ is the total number of seeds. Rate of recovery was also calculated by the method of Edmond and Drapala (1958) using the percentage of recovery data. Germination and recovery germination data were arcsine transformed before statistical analysis to ensure homogeneity of variance. Analysis of variance (ANOVA) was carried out to determine whether significant differences were present among means because of the individual and interactive effects of seed lot, salinity, temperature, and photoperiod (SPSS 2002). A post hoc Bonferroni test was used to determine whether significant differences were present among individual salinity treatments. Linear regression was plotted to compare the differences in germination (light and dark) and recovery responses in different temperature regimes (SPSS 2002).

\section{RESULTS}

The 3-way ANOVA indicated significant effects of salinity $\left(\mathrm{F}_{5,94}=229, \quad P<0.0001\right), \quad$ temperature $\quad\left(\mathrm{F}_{3,94}=166\right.$, $P<0.0001)$, photoperiod $\left(\mathrm{F}_{1,94}=206, P<0.0001\right)$, and their interactions on seed germination of D. bipinnata (Table 1). Seed germination was highest $\left(96 \%\right.$ at $\left.25^{\circ}-35^{\circ} \mathrm{C}\right)$ in the nonsaline control, and increases in salinity resulted in concomitant decreases in seed germination, with only $30 \%$ seeds germinating in $500 \mathrm{mM} \mathrm{NaCl}$ at the optimal temperature regime of $25^{\circ}-35^{\circ} \mathrm{C}$ (Fig. 1). No seed germinated above $200 \mathrm{mM} \mathrm{NaCl}$ at $10^{\circ}-20^{\circ} \mathrm{C}$ (Fig. 1). Seed germination was higher at all salinity concentrations at temperature regimes above $15^{\circ}-25^{\circ} \mathrm{C}$. The higher temperatures showed similar final germination percentages at most salinities except for 400 and $500 \mathrm{mM} \mathrm{NaCl}$, where germination was about twice as much at $25^{\circ}-35^{\circ} \mathrm{C}$ in comparison to $20^{\circ}-30^{\circ} \mathrm{C}$ (Fig. 1).

Seed germination decreased substantially in both saline and nonsaline treatments in dark compared with germination in photoperiod (Table 1). Higher temperature regimes at higher salinity concentrations inhibited seed germination (Fig. 2).

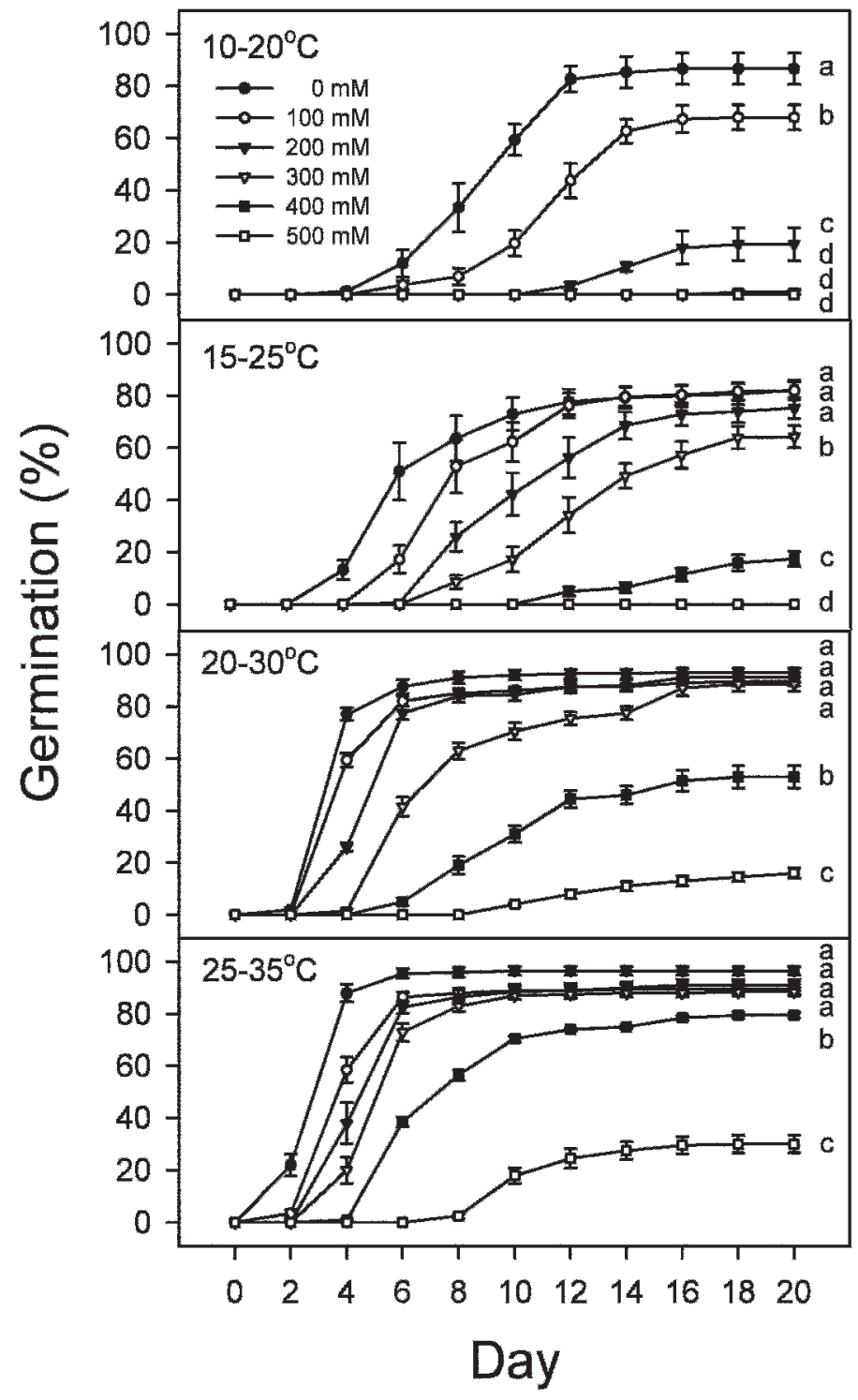

Figure 1. Percentage of seed germination of Desmostachya bipinnata in various salinity $(0,100,200,300,400$, and $500 \mathrm{mM} \mathrm{NaCl})$ and temperature $\left(10^{\circ}-20^{\circ}, 15^{\circ}-25^{\circ}, 20^{\circ}-30^{\circ}\right.$, and $\left.25^{\circ}-35^{\circ} \mathrm{C}\right)$ regimes. Data points represent mean ( $\pm \mathrm{SE} ; n=3$ ) of 3 replications for each temperature treatment with 4 subsamples of each salinity treatment.

When seeds were transferred to distilled water after 20 days of salinity treatment, the recovery germination percentages increased with increase in pretransfer salinity at all temperatures except for the lowest temperature regime of $10^{\circ}-20^{\circ} \mathrm{C}$ (Fig. 3). Seeds subjected to higher temperatures had higher recovery percentages (Fig. 3), but at the lowest temperature $\left(10^{\circ}-20^{\circ} \mathrm{C}\right)$, recovery was lower $(8 \%$ from $500 \mathrm{mM} \mathrm{NaCl})$. Rate of germination $\left(\mathrm{R}_{\mathrm{Ger}}\right)$ increased progressively with increasing salinity at all temperatures. Most seed germinated within 6 days of salinity treatment in up to $200 \mathrm{mM} \mathrm{NaCl}$, whereas at higher salinities, seeds required about 14 days to achieve maximum seed germination (Fig. 1; Table 2). Rate of recovery germination $\left(R_{R e c}\right)$ showed relatively higher values in seeds from the higher salt pretreatment concentrations and at lower temperatures (Table 2). Maximum recovery of about $80 \%$ was observed within 4 days of transfer from saline conditions. 


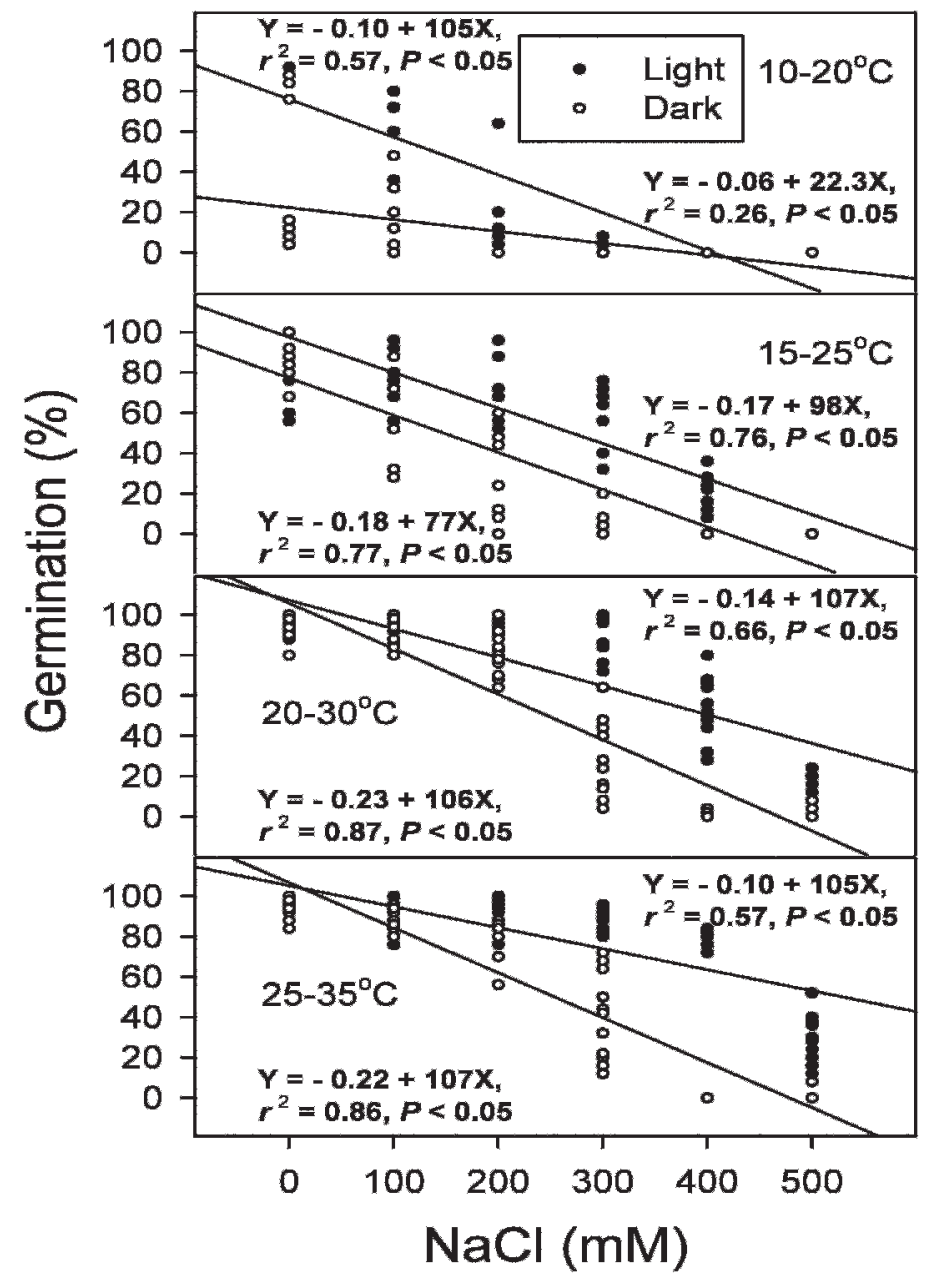

Figure 2. Linear regression for final germination percentages of Desmostachya bipinnata seeds after 20 days at various salinity $(0$, $100,200,300,400$, and $500 \mathrm{mM} \mathrm{NaCl})$, temperature $\left(10^{\circ}-20^{\circ}, 15^{\circ}-25^{\circ}\right.$, $20^{\circ}-30^{\circ}$, and $25^{\circ}-35^{\circ} \mathrm{C}$ ), and photoperiod (12-h light: 12-h dark, and 24h dark) regimes.

\section{DISCUSSION}

Seed germination is affected by many factors, such as temperature, light, and soil moisture (Zheng et al. 2004); however, the dominant abiotic factor affecting seed germination varies among species and partially accounts for the differences in timing of germination in the field (Noe and Zedler 2000). This study was designed to test 7 hypotheses, and we learned by testing those hypotheses that seeds of $D$. bipinnata germinate better under nonsaline conditions; however, some seeds could germinate at $>400 \mathrm{mM} \mathrm{NaCl}$. Temperature and light played a significant role in seed germination. Seeds maintained viability when exposed to high salinity and recovery was higher at higher-temperature regimes. Salinity, temperature, photoperiod, and their interactions significantly affected seed germination of $D$. bipinnata. Seeds appeared to have high salinity tolerance at higher temperatures in the presence of light.

Seeds of subtropical grasses are usually nondormant at maturity (Khan and Ungar 1999; Gulzar et al. 2001; Gulzar and Khan 2001) except for S. ioclados (Khan and Gulzar 2003), which shows $<40 \%$ germination under nonsaline

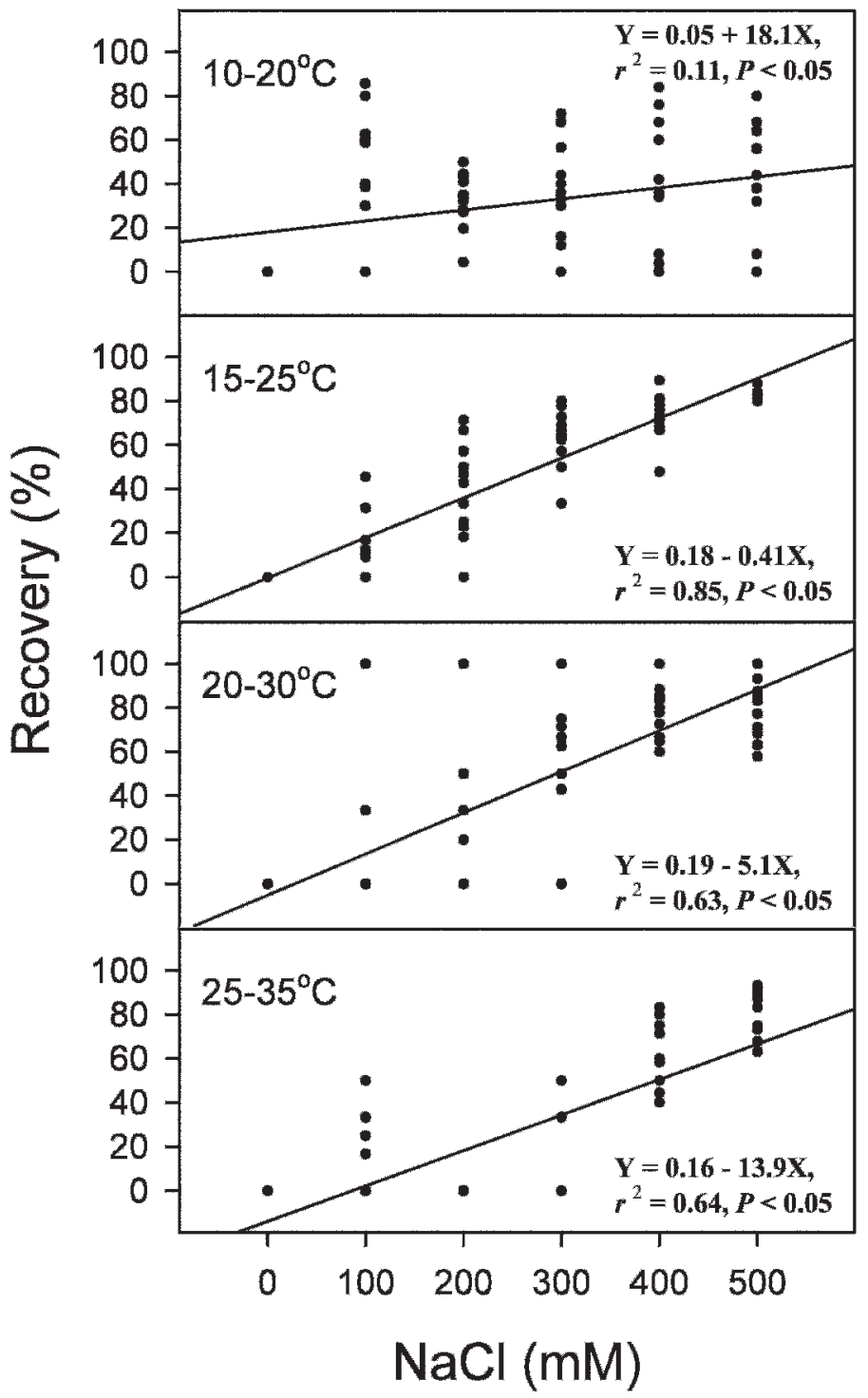

Figure 3. Linear regression for percentage of recovery germination for Desmostachya bipinnata seeds transferred to distilled water from various salinity $(0,100,200,300,400$, and $500 \mathrm{mM} \mathrm{NaCl})$ and at the same temperature $\left(10^{\circ}-20^{\circ}, 15^{\circ}-25^{\circ}, 20^{\circ}-30^{\circ}\right.$, and $\left.25^{\circ}-35^{\circ} \mathrm{C}\right)$ regimes.

conditions. Seeds of D. bipinnata were also nondormant, and almost all seeds germinated under optimal environmental conditions. Seed germination of halophytes tends to decrease with increase in salinity (Ungar 1995; Khan and Gul 2006) except for more salt-tolerant grasses, such as Elytrigia elongata (Host) Nevski., which had $60 \%$ germination at $445 \mathrm{mM} \mathrm{NaCl}$ and Spartina alterniflora Loisel., the most salt-tolerant grass reported, with salt tolerance of up to $6 \%$ (about $1027 \mathrm{mM}$ ) $\mathrm{NaCl}$ (Mooring et al. 1971). The threshold salinity for significant reduction in germination varies with grass species and mostly ranges between $100-500 \mathrm{mM} \mathrm{NaCl}$ and subtropical grasses appear to be quite salt-tolerant approaching seawater salinity (about $500 \mathrm{mM} \mathrm{NaCl}$; Khan and Gulzar 2003). Inhibition or delay in germination under saline conditions is due to an osmotic effect (Khan and Ungar 1997a; Khan and Gulzar 2003), which limits the uptake of water during seed germination (Murillo-Amador et al. 2002) rather than ion toxicity (Hyder and Yasmin 1972) by hindering 
Table 2. Rates of germination $\left(\mathrm{R}_{\mathrm{Ger}}\right)$ and recovery $\left(\mathrm{R}_{\mathrm{Rec}}\right)$ of Desmostachya bipinnata seeds in response to variable salinity $(0,100$, $200,300,400$, and $500 \mathrm{mM} \mathrm{NaCl})$ and temperature $\left(10^{\circ}-20^{\circ}, 15^{\circ}-25^{\circ}\right.$, $20^{\circ}-30^{\circ}$, and $25^{\circ}-35^{\circ} \mathrm{C}$ ) regimes. Numbers in parentheses show water potential of each $\mathrm{NaCl}$ solution at $35^{\circ} \mathrm{C}$. Letters for rates (mean $\pm \mathrm{SE} ; n$ $=3)$ in columns are not significantly $(P<0.05)$ different from each other between different salinities, Bonferroni test.

\begin{tabular}{|c|c|c|c|c|c|c|c|c|}
\hline \multirow{2}{*}{$\begin{array}{l}\mathrm{NaCl}\left(\psi_{w}\right) \\
\mathrm{mM}(-\mathrm{MPa})\end{array}$} & \multicolumn{2}{|c|}{$10^{\circ}-20^{\circ} \mathrm{C}$} & \multicolumn{2}{|c|}{$15^{\circ}-25^{\circ} \mathrm{C}$} & \multicolumn{2}{|c|}{$20^{\circ}-30^{\circ} \mathrm{C}$} & \multicolumn{2}{|c|}{$25^{\circ}-35^{\circ} \mathrm{C}$} \\
\hline & $\mathrm{R}_{\mathrm{Ger}}$ & $\mathrm{R}_{\mathrm{Rec}}$ & $\mathrm{R}_{\mathrm{Ger}}$ & $\mathrm{R}_{\mathrm{Rec}}$ & $\mathrm{R}_{\mathrm{Ger}}$ & $\mathrm{R}_{\mathrm{Rec}}$ & $\mathrm{R}_{\mathrm{Ger}}$ & $\mathrm{R}_{\mathrm{Rec}}$ \\
\hline \multirow[t]{2}{*}{0} & $9 \mathrm{a}$ & $0 \mathrm{a}$ & $8 \mathrm{a}$ & $0 \mathrm{a}$ & $5 a$ & $0 \mathrm{a}$ & $4 \mathrm{a}$ & $0 \mathrm{a}$ \\
\hline & \pm 0 & & \pm 1 & & \pm 2 & & \pm 0 & \\
\hline \multirow[t]{2}{*}{$100(0.45)$} & $12 b$ & $6 \mathrm{~b}$ & $10 \mathrm{~b}$ & $2 \mathrm{~b}$ & $5 \mathrm{a}$ & $1 \mathrm{~b}$ & $5 b$ & $1 \mathrm{~b}$ \\
\hline & \pm 0 & \pm 1 & \pm 1 & \pm 1 & \pm 0 & \pm 1 & \pm 1 & \pm 1 \\
\hline \multirow[t]{2}{*}{$200(0.97)$} & $14 \mathrm{c}$ & $5 \mathrm{~b}$ & $12 b$ & $4 \mathrm{C}$ & $6 \mathrm{a}$ & $1 \mathrm{~b}$ & $6 \mathrm{~b}$ & $0 \mathrm{a}$ \\
\hline & \pm 0 & \pm 0 & \pm 2 & \pm 0 & \pm 1 & \pm 1 & \pm 0 & \\
\hline \multirow[t]{2}{*}{$300(1.43)$} & $0 d$ & $3 c$ & $13 b$ & $4 \mathrm{c}$ & $9 \mathrm{~b}$ & $4 \mathrm{c}$ & $6 \mathrm{~b}$ & $1 \mathrm{~b}$ \\
\hline & & \pm 1 & \pm 1 & \pm 0 & \pm 0 & \pm 1 & \pm 0 & \pm 0 \\
\hline \multirow[t]{2}{*}{$400(1.93)$} & $0 \mathrm{~d}$ & $9 \mathrm{~d}$ & $16 c$ & $4 \mathrm{C}$ & $11 \mathrm{c}$ & $4 \mathrm{C}$ & $8 c$ & $4 \mathrm{c}$ \\
\hline & & \pm 1 & \pm 1 & \pm 0 & \pm 0 & \pm 0 & \pm 0 & \pm 0 \\
\hline \multirow[t]{2}{*}{$500(2.40)$} & $0 \mathrm{~d}$ & $9 \mathrm{~d}$ & $0 \mathrm{~d}$ & $4 \mathrm{c}$ & $14 \mathrm{~d}$ & $4 \mathrm{C}$ & $11 d$ & $4 \mathrm{c}$ \\
\hline & & \pm 1 & & \pm 0 & \pm 1 & \pm 0 & \pm 1 & \pm 0 \\
\hline
\end{tabular}

activity of membrane or cytosolic enzymes and hormones (Bewley and Black 1994). However, both ionic and toxic effects may be involved to varying degrees in different taxa (Allen et al. 1986), and death is the cause of low seed germination in some species (Khan and Gulzar 2003). Mahmood and Malik (1996) found that the grasses Cynodon dactylon (L.) Pers., D. bipinnata, Polypogon monospeliensis (L.) Desf., and Sporobolus arabicus Boiss. showed a decrease in germination with increase in salinity from 3 to $20 \mathrm{dS} \cdot \mathrm{m}^{-1}$. Only D. bipinnata exhibited salt stimulation at low salinity $\left(5 \mathrm{dS} \cdot \mathrm{m}^{-1}\right.$ or $52 \mathrm{mM}$ $\mathrm{NaCl})$ and had $40 \%$ germination at $20 \mathrm{dS} \cdot \mathrm{m}^{-1}(206 \mathrm{mM}$ $\mathrm{NaCl}$ ) with no seed germinating beyond this level. Grasses like P. coloratum L. (Perez et al. 1998), P. hemitimon Schult. (Hester et al. 1998), U. setulosa (Gulzar et al. 2001), A. lagopoides (Gulzar and Khan 2001), and S. ioclados (Khan and Gulzar 2003) germinate well in up to $200 \mathrm{mM} \mathrm{NaCl}$ concentrations, but at higher salt concentrations, germination was substantially reduced. $H$. mucronatum also showed reduced germination above $200 \mathrm{mM} \mathrm{NaCl}$, and seeds failed to germinate beyond $350 \mathrm{mM} \mathrm{NaCl}$ (Khan and Ungar 2001). In this study, D. bipinnata seeds had $>80 \%$ germination at $200 \mathrm{mM} \mathrm{NaCl}$.

Temperature has a major impact in regulating phenology and distribution of halophytes in arid and semiarid environments (Khan and Ungar 1997b; Khan and Gulzar 2003). Decreased germination at suboptimal temperatures may accelerate degradative metabolic processes (Bewley and Black 1994). Most subtropical grasses germinate best at $20^{\circ}-30^{\circ} \mathrm{C}$, and extreme thermoperiods inhibit seed germination and rate of germination of these species (Khan and Gulzar 2003). Seeds of Panicum turgidum Forssk. appeared to germinate better in the intermediate incubation temperatures of $15^{\circ}-25^{\circ}$ and $20^{\circ}-30^{\circ} \mathrm{C}$ (Al-Khateeb 2006). Better germination as well as recovery was observed in the case of D. bipinnata at higher temperatures $25^{\circ}-35^{\circ} \mathrm{C}$ would confer a competitive advantage over other cooccurring species either at the onset of, or soon after, monsoon rains. Similar results were obtained for Leptochloa chinensis L. Nees., a weed of Italian rice fields (Benevenuti et al. 2004).

Seed germination response of halophytes to light is highly variable and may range from an obligate requirement to a slight stimulation or a slight inhibition, from no effect to complete germination inhibition (Baskin and Baskin 1998). This may be a mechanism of preventing germination when seeds are buried in the soil, covered by leaf litter or by a muddy layer, or flooded by a high water level (Schütz and Rave 1999; Hroudová and Zakravski 2003). Light is perceived by phytochrome (Borthwick et al. 1954); thus, germination onset or inhibition is a function of incident radiation capable of activating phytochrome that absorbs far red light (Pfr) or inactivating phytochrome that absorbs red light $(\operatorname{Pr})$ (Benvenuti et al. 2004). Phytochrome-dependent light response is a frequent natural process within species that colonize open areas (Ballaré 1994). Lack of or lower germination during burial would allow seeds to escape fatal germination (Mapes et al. 1989) as in $L$. chinensis (Benvenuti et al. 2004). Absence of light did not affect germination of $U$. setulosa and $H$. mucronatum, slightly stimulated A. lagopoides, and greatly inhibited seed germination in S. ioclados and S. arabicus (Khan and Ungar 2001; Khan and Gulzar 2003). Light promoted seed germination of D. bipinnata at salinity treatments greater than $200 \mathrm{mM} \mathrm{NaCl}$ in the higher thermoperiod regimes, whereas at lower thermoperiod and salinity regimes, fewer differences were observed between the photoperiod and dark germinated seeds.

Halophytes show variable recovery of germination responses after exposure to high salinity and temperature stress (Shen et al. 2003). This variation in recovery responses could be helpful for survival of plants following salt stress. A. lagopoides (Gulzar and Khan 2001) and U. setulosa (Gulzar et al. 2001) showed a high $(85 \%)$ recovery at $600 \mathrm{mM} \mathrm{NaCl}$ at $20^{\circ}-30^{\circ} \mathrm{C}$, whereas S. ioclados (Khan and Gulzar 2003) showed overall poor recovery response. Macke and Ungar (1971) found 87\% recovery in seeds of Puccinellia nuttalliana (Schult.) Hitchc. in distilled water in comparison to $5.2 \%$ after 45 days of exposure to $2 \% \mathrm{NaCl}$. Percentage and rate of germination of Hordeum jubatum L. decreased after extended exposure to hypersaline conditions, and no recovery was obtained after 1 year in $10 \% \mathrm{NaCl}$ (Keiffer and Ungar 1997). Most seeds of D. bipinnata recovered after 20 days exposure to $500 \mathrm{mM}$ $\mathrm{NaCl}$ at $25^{\circ}-35^{\circ} \mathrm{C}$, which indicated an osmotic, rather than a toxic, effect of salinity. Recovery was also high at the higher thermoperiod as opposed to better recovery at $20^{\circ}-30^{\circ} \mathrm{C}$, the moderate thermoperiod regime for other co-occurring grasses.

\section{MANAGEMENT IMPLICATIONS}

D. bipinnata occurs in habitats ranging from riverbeds to moist salt flats under warm temperatures. This grass has relatively high protein content and could be a good fodder. Young plants are grazed; however, older plants with hard fibers injure the mouth of the animals. Our field trials indicate that this species could be used as a dry fodder and grown by using brackish water (up to $10 \mathrm{dS} \cdot \mathrm{m}^{-2}$ or about $100 \mathrm{mM} \mathrm{NaCl}$ ) irrigation. Dry fodder, which is about $85 \%$ of the total food consumed by livestock, contributes significantly in developing livestock in areas where freshwater supply is limited. Production, nutrition 
levels or grazing value, productivity, quality, and palatability of D. bipinnata are being investigated.

The high temperature and salinity tolerance of our test species would support late sowing in the field; however, because germination is only the first phase in establishment and growth, it is difficult to make inferences about irrigation with saline water and subsequent growth and productivity. Further research on D. bipinnata could confirm these traits and provide useful information in better using this grass as a fodder plant.

\section{LITERATURE CITED}

AL-KhateeB, S. A. 2006. Effect of salinity and temperature on germination, growth, and ion relations of Panicum turgidum Forssk. Bioresource Technology 97:292-298.

Allen, S. G., A. K. Dobrenz, and P. G. Bartels. 1986. Physiological response of salttolerance and non-tolerant alfalfa to salinity during germination. Crop Science 26:1004-1008.

Aronson, J. A. 1989. Haloph, a data base of salt tolerant plants of the world. Tucson, AZ: Office of Arid Land Studies, University of Arizona Press. 77 p.

BallaRÉ, C. L. 1994. Light gaps: Sensing the light opportunities in highly dynamic canopy environments. In: M. M. Caldwell and R. W. Percy [EDs.]. Exploitation of environmental heterogeneity by plants: Ecophysiological processes above and belowground. San Diego, CA: Academic Press. p. 73-110.

BASKIN, C. C., AND J. M. BASKIn. 1998. Seeds ecology, biogeography, and evolution of dormancy and germination. San Diego, CA: Academic Press. 666 p.

Benevenuti, S., G. Dinelli, and A. Bonetti. 2004. Germination ecology of Leptochloa chinensis: a new weed in the Italian rice agro-environment. Weed Research 44:87-96.

Bewley, J. D., and M. Black. 1994. Seeds: Physiology of development and germination. New York, NY: Plenum Press. 445 p.

Borthwick, H. A., S. B. Hendricks, E. H. Toole, and V. K. Toole. 1954. Action of light on lettuce seed germination. Botanical Gazette 115:205-225.

Breen, C. M., C. Everson, and K. Rogers. 1997. Ecological studies on Sporobolus virginicus $(\mathrm{L})$ Kunth with particular reference to salinity and inundation. Hydrobiologia 54:135-140.

Cope, T. A. 1982. Poaceae. In: E. Nasir and S. I. Ali [eds.]. Flora of Pakistan. Karachi, Pakistan: University of Karachi, Pakistan. 678 p.

Dagar, J. C., O. S. Tomar, Y. Kumar, and R. K. Yadav. 2004. Growing three aromatic grasses in different alkali soils in semi-arid regions of Northern India. Land Degradation and Development 15:143-151.

Debez, A., B. H. Hamed, C. Grignon, and C. Abdelly. 2004. Salinity effects on germination, growth and seed production of the halophyte Cakile maritima. Plant and Soil 262:179-189.

Dodd, G. L., And L. A. Donovan. 1999. Water potential and ionic effects on germination and seedling growth of two cold desert shrubs. American Journal of Botany 86:1146-1153.

Edmond, J. B., and W. J. Drapala. 1958. The effects of temperature, sand and soil, and acetone on germination of okra seed. Proceedings of the American Society for Horticultural Science 71:428-434.

Godol, S., AND M. TAKAKI. 2004. Effects of light and temperature on seed germination in Cercopia hololeuca Miq. (Cercopiaceae) Brazilian Archives of Biology and Technology 47:185-191.

GUL, B., AND WEBER, D. J. 1999. Effect of salinity, light and temperature on germination in Allenrolfea occidentalis. Canadian Journal of Botany 77:240-246.

GulzaR, S. 2002. Effect of salinity on germination, dormancy, growth and osmoregulation of perennial halophytes [dissertation]. Karachi, Pakistan: University of Karachi, Pakistan. $184 \mathrm{p}$.

Gulzar, S., And M. A. Khan. 2001. Seed germination of a halophytic grass Aeluropus lagopoides. Annals of Botany 87:319-324.

Gulzar, S., M. A. Khan, and I. A. Ungar. 2001. Effect of salinity and temperature on the germination of Urochondra setulosa. Seed Science and Technology $29: 21-29$
Hester, M. W., I. A. Mendelssohn, and K. L. McKee. 1998. Intraspecific variation in salt tolerance and morphology in Panicum hemitomon and Spartina alterniflora (Poaceae). International Journal of Plant Science 159:127-139.

Hroudová, Z., AND P. Zákravsky. 2003. Germination responses of diploid Butomus umbellatus to light, temperature and flooding. Flora 198:37-44.

Hyder, S. Z., AND S. YASMIN. 1972. Salt tolerance and cation interaction in alkali sacaton at germination. Journal of Range Management 25:390-392.

Joshi, A. J., AND A. S. Bholte. 1988. Fluctuation of mineral ions in saline soils and halophytic grass Aeluropus lagopoides L. Annals of Arid Zone 27:191-196.

Joshi, A. J., B. S. Mali, And H. HinglaJiA. 2005. Salt tolerance at germination and early growth of two forage grasses growing in marshy habitats. Environmental and Experimental Botany 54:267-274.

KelfFer, C. W., and I. A. Ungar. 1997. The effect of extended exposure to hypersaline conditions on the germination of five inland halophyte species. American Journal of Botany 84:104-111.

Khan, M. A., And B. Gul. 2006. Halophyte seed germination. In: M. A. Khan and D. J. Weber [EDS.]. Eco-physiology of high salinity tolerant plants. Dordrecht, The Netherlands: Springer. p. 11-30.

Khan, M. A., And S. Gulzar. 2003. Light, salinity and temperature effects on the seed germination of perennial grasses. American Journal Botany 90:131-134.

Khan, M. A., AND I. A. Ungar. 1997a. Effect of thermoperiod on recovery of seed germination of halophytes from saline conditions. American Journal Botany 84:279-283.

Khan, M. A., And I. A. Ungar. 1997b. Effect of light, salinity, and thermoperiod on the seed germination of halophytes. Canadian Journal of Botany 75:835-841.

Khan, M. A., and I. A. Ungar. 1999. Effect of salinity on the seed germination of Triglochin maritima under various temperature regimes. Great Basin Naturalist 59:144-150.

Khan, M. A., And I. A. Ungar. 2001. Alleviation of salinity stress and the response to temperature stress in two seed morphs of Halopyrum mucronatum (Poaceae). Australian Journal Botany 49:777-783.

Lang, A. R. G. 1967. Osmotic coefficients and water potentials of sodium chloride solutions from 0 to $40^{\circ} \mathrm{C}$. Australian Journal of Chemistry 20:2017-2023.

Lieth, H., M. Moschenko, H. Lohman, H. W. Koyro, and A. Hamdy. 1999. Halophyte uses in different climates, I: ecological and ecophysiological studies. In: Progress in biometeriology. Volume 13. Leiden, The Netherlands: Backhuys Publishers.

Macke, A., And I. A. Ungar. 1971. The effect of salinity on germination and early growth of Puccinellia nuttalliana. Canadian Journal of Botany 49:515-520.

Mahmood, K., AND K. A. MaliK. 1996. Seed germination and salinity tolerance in plant species growing on saline wastelands. Biologia Plantarum 38:309-315.

Mapes, G. G., W. Rothwell, and M. T. Haworth. 1989. Evolution of seed dormancy. Nature 337:645-646.

Mooring, M. T., A. W. Cooper, and E. D. Seneca. 1971. Seed germination response and evidence for height of ecophenes in Spartina alterniflora from North Carolina. American Journal of Botany 58:48-56.

Murillo-Amador, B., R. Lopez-Agullar, C. Kaya, J. Larrinaga-Mayoral, and A. FloresHernandez. 2002. Comparative effects of $\mathrm{NaCl}$ and polyethylene glycol on germination, emergence and seedling growth of cowpea. Journal of Agronomy and Crop Science 188:235-247.

NoE, G. B., AND J. B. ZedLer. 2000. Differential effects of four abiotic factors on the germination of salt marsh annuals. American Journal of Botany 87: 1679-1692.

Perez, T., C. Moreno, G. L. Seffino, A. Grunber, and Z. Bravo. 1998. Salinity effects on the early development stages of Panicum coloratum: cultivar differences. Grass and Forage Science 53:270-278.

Redondo, S., A. E. Rubio-Casal, J. M. Castillo, C. J. Luque, A. A. Álvarez, T. Luque, AND M. E. FigueroA. 2004. Influences of salinity and light on germination of three Sarcornia taxa with contrasted habitats. Aquatic Botany 78:255-264.

Schütz, W., AND G. Rave. 1999. The effect of cold stratification and light on the seed germination of temperate sedges (Carex) from various habitats and implications for regenerative strategies. Plant Ecology 144:215-230.

Shen, Y., Y. LI, AND S. G. Yan. 2003. Effects of salinity on germination of six salttolerant forage species and their recovery from saline conditions. New Zealand Journal of Agricultural Research 46:263-269. 
SPSS. 2002. Statistical Package for the Social Sciences for Windows. Version 11.5. Chicago, IL: SPSS Inc.

Tester, M., and C. Morris. 1987. The penetration of light through soil. Plant Cell and Environment 10:281-286.

UngaR, I. A. 1995. Seed germination and seed-bank ecology in halophytes. In: J. Kigel and G. Galili [EDS.]. Seed development and seed germination. New York, NY: Marcel Dekker. p. 599-628.
Zheng, Y., Z. Xie, Y. Gao, L. Jiang, H. Shimizu, and K. Tobe. 2004. Germination responses of Caragana korshinskii Kom. to light, temperature and water stress. Ecological Research 19:553-558.

ZIA, S., AND M. A. Khan. 2002. Comparative effect of $\mathrm{NaCl}$ and seawater on seed germination of Limonium stocksii. Pakistan Journal of Botany 34:345-350.

ZIA, S., AND M. A. Khan. 2004. Effect of light, salinity and temperature on seed germination of Limonium stocksii. Canadian Journal of Botany 82:151-157. 